\title{
Picophytoplankton and carbon cycle on the northeastern shelf of the Gulf of Cádiz (SW Iberian Peninsula)
}

\author{
MARIANA RIBAS-RIBAS ${ }^{1,4}$, CRISTINA SOBRINO ${ }^{2}$, BIBIANA DEBELIUS ${ }^{1}$, LUÍS M. \\ LUBIÁN $^{3}$, ROCIO PONCE ${ }^{1}$, ABELARDO GÓMEZ-PARRA $^{1}$ and JESÚS M. FORJA ${ }^{1}$ \\ ${ }^{1}$ Departamento de Química Física, Facultad de Ciencias del Mar y Ambientales, Universidad de Cádiz, Campus Río San \\ Pedro s/n, 11510 Puerto Real, Cádiz, Spain.E-mail: mariana.ribas@uca.es; m.ribas-ribas@ soton.ac.uk \\ ${ }^{2}$ Departamento de Ecoloxía e Bioloxía Animal, Facultad de Ciencias, Universidad de Vigo, Campus Lagoas Marcosende, \\ 36310 Vigo, Pontevedra, Spain. \\ ${ }^{3}$ Instituto de Ciencias Marinas de Andalucía, CSIC, Campus Río San Pedro s/n, 11510 Puerto Real, Cádiz, Spain. \\ ${ }^{4}$ Present address: School of Ocean and Earth Science, National Oceanography Centre, Southampton, \\ University of Southampton, Waterfront Campus, European Way, Southampton SO14 3ZH, UK.
}

SUMMARY: Four surveys (Jun'06 and Nov'06; Feb'07 and May'07) were carried out on the northeastern shelf of the Gulf of Cádiz (southwest Iberian Peninsula) to relate the spatio-temporal distribution of the carbon cycle parameters (dissolved inorganic carbon and dissolved organic carbon) to picophytoplankton biomass and community composition. In addition, the net ecosystem production and the picophytoplankton contribution to the air-sea $\mathrm{CO}_{2}$ exchange process were investigated. The results showed that chlorophyll- $a$, carbon cycle parameters and picophytoplankton composition showed large seasonality, and the Guadalquivir Estuary plays an important role in the contribution of nutrient and suspended particular material over the year. Regarding picophytoplankton composition, the flow cytometry analysis demonstrated that Prochlorococcus and Synechococcus were the main populations in the studied area and their temporal and spatial distributions were complementary: the Prochlorococcus population showed its maximum concentration in May'07 and Jun'06 and in the surface oceanic water, whereas the Synechococcus population was at its maximum during Feb'07 and Nov'06, and off the Guadalquivir Estuary and Bay of Cádiz. In addition, a relationship between the studied parameters and the fugacity of $\mathrm{CO}_{2}$ was also observed, suggesting that primary production is an important factor in the regulation of this parameter in the studied area. The calculated carbon budget showed that the area acts as a carbon sink on an annual basis.

Keywords: carbon cycle, chlorophyll- $a$, picophytoplankton, seasonal variations, coastal zone, Guadalquivir Estuary, Gulf of Cádiz.

RESUMEN: Picofitoplancton y Ciclo del CARbono en la plataforma CONTinental noReste del golfo de CÁdiz (SO PENÍNSULA IBÉRICA). - Se llevaron a cabo cuatro campañas oceanográficas (Jun'06 y Nov'06; Feb'07 y May'07) en la plataforma continental noreste del golfo de Cádiz (suroeste de la península Ibérica) para relacionar la distribución espaciotemporal de los parámetros del ciclo del carbono (carbono inorgánico disuelto y carbono orgánico disuelto) con la biomasa picofitoplanctónica y la composición de la comunidad. Además, se investigó la producción neta del ecosistema y la contribución del picofitoplancton al proceso de intercambio atmósfera-agua de $\mathrm{CO}_{2}$. Los resultados mostraron que la clorofila- $a$, los parámetros del ciclo del carbono y la composición del picofitoplancton presentaron una gran estacionalidad, jugando el estuario del Guadalquivir un papel importante en la contribución de nutrientes y material particulado en suspensión a lo largo del año. Los análisis de citometría demostraron que Prochlorococcus y Synechococcus fueron las principales poblaciones en el área de estudio y que su distribución espacial y temporal fue complementaria: Prochlorococcus presentó la máxima concentración en primavera y verano en aguas superficiales oceánicas, mientras que Synechococcus en invierno y otoño en aguas someras. Además, se observó una relación entre los parámetros estudiados y fugacidad de $\mathrm{CO}_{2}$, lo que sugiere que la producción primaria es un factor importante en la regulación de este parámetro en el área de estudio. El balance de carbono calculado indicó que el área actúa como sumidero de carbono a escala anual.

Palabras claves: ciclo del carbono, clorofila- $a$, picofitoplancton, variaciones estacionales, zona costera, estuario del Guadalquivir, golfo de Cádiz. 


\section{INTRODUCTION}

The evaluation of biological processes such as $\mathrm{CO}_{2}$ fixation by phytoplankton communities in surface ocean waters and their associated role in the air-sea $\mathrm{CO}_{2}$ exchange has become a key issue during recent years (Arrigo and Van Dijken 2007). However, the influence of carbon withdrawal brought about by different phytoplankton taxonomic groups on the $\mathrm{CO}_{2}$ fluxes between the atmosphere and the water column has not yet been extensively considered (Macías et al. 2009).

Among the different groups, the picophytoplankton is one of the main contributors to global ocean primary production (Agawin et al. 2000), especially in the central oligotrophic regions of the world oceans that have very low concentrations of nutrients ( $\mathrm{Li}$ et al. 1983). In this study we focused on the picophytoplanktonic fraction of the phytoplankton, defined as those cells $\leq 2$ $\mu \mathrm{m}$, because of their ubiquity, abundance, and persistence, all of which contribute to their potential importance to primary production and carbon cycling. One of the most abundant picophytoplankters, Synechococcus, is known to make a relatively large contribution to photosynthetic phytoplankton in inshore or coastal ecosystems (Jochem 1988). A previous study in a coastal Mediterranean system also indicated that the significant contribution of Synechococcus to the total autotrophic biomass and production during summer was an important source of organic $\mathrm{C}$ and nutrients for the planktonic food web (Agawin et al. 1998).

In the NE Atlantic, Donald et al. (2001) found that picophytoplankton dominated below $37^{\circ} \mathrm{N}$. Knowledge of the picophytoplankton distribution and biomass is rather limited in the Gulf of Cádiz $\left(36^{\circ} \mathrm{N}\right.$, $6^{\circ} \mathrm{W}$ ), and consequently little is known about the influence of these organisms on the carbon cycling of this area. Among the published work related to the area and topic of study, Huertas et al. (2005) studied the influence of phytoplankton biomass and physicochemical variables on the $\mathrm{CO}_{2}$ concentration under a spring bloom, and Echevarría et al. (2009) analyzed the distribution pattern of picoplanktonic autotrophs during summer. However, as far as we know, there are no published studies linking these variables over an annual cycle, which clearly hampers our ability to estimate the influence of picophytoplankton on the annual carbon cycle of the northeastern shelf of the Gulf of Cádiz. The importance and novelty of this work is to report a yearly C cycle in the Gulf of Cádiz, an area of significant interest in oceanic processes and biological production.

Considering the lack of knowledge about this topic the main objective of this study was to define the role of picophytoplankton in the carbon budget, and to determine the importance of this phytoplankton fraction in the studied area over the year. The specific objectives were: (i) to determine the relation between the carbon system and the phytoplanktonic biological activity; and (ii) to examine which environmental factors control

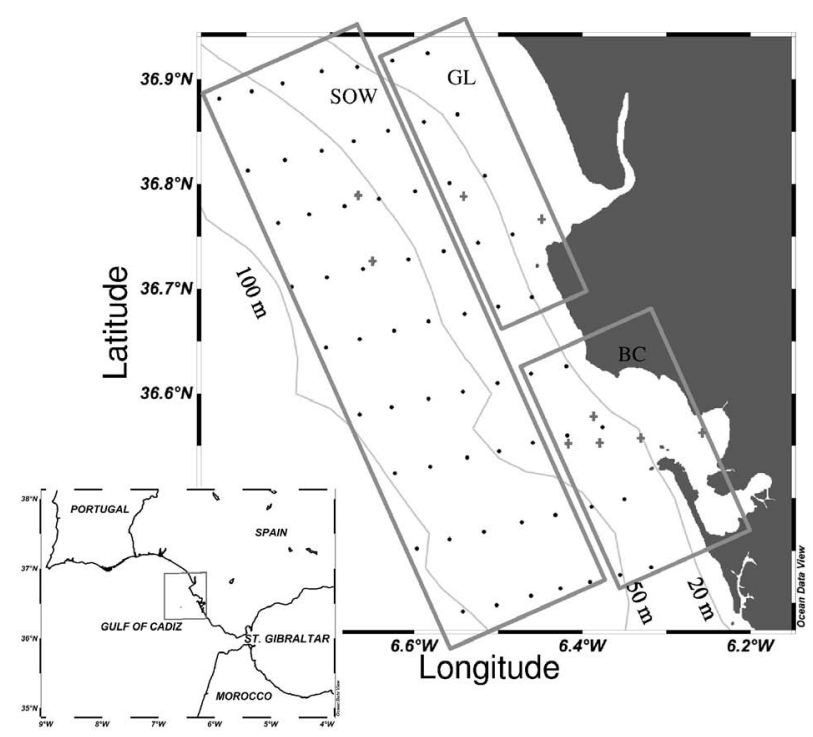

FIG. 1. - Map of the northeastern shelf of the Gulf of Cádiz, specifying the border of the areas: Guadalquivir Estuary (GL), Bay of Cádiz (BC) and surface oceanic water (SOW). The grid indicates the sampling stations for the four cruises, showing different transects. The crosses indicate the extra stations off GL and BC undertaken during Jun'06, Nov'06 and Feb'07. Isolines represent the bathymetry.

and/or influence the spatial and temporal variations of the picophytoplankton populations on the northeastern shelf of the Gulf of Cádiz.

\section{MATERIALS AND METHODS}

\section{Studied area}

The study was carried out over the northeastern shelf of the Gulf of Cádiz, which is located on the southwestern coast of the Iberian Peninsula (Fig. 1). Anfuso et al. (2010) identified four different water masses in this area: North Atlantic Central Water (NACW), Surface Atlantic Water, considered a modification of NACW, and South and North Surface Waters. The basin receives significant fluvial inputs associated with the discharge of large rivers such as the Guadalquivir River. The Guadalquivir River is the main fluvial source draining into the Gulf of Cádiz margin. Coastal waters near the mouth of the Guadalquivir River and in the Bay of Cádiz show the highest primary production within the Gulf of Cádiz (Navarro and Ruiz 2006). The coastal fringe of the Gulf of Cádiz is also characterized by the presence of waters warmer and colder than those detected in the rest of the basin during Jun'06 and Feb'07 respectively (Vargas et al. 2003, Navarro and Ruiz 2006) and by a strong meteorological forcing caused by quasi-permanent wind episodes. The predominance of western winds is always linked to the generation of upwelling events and therefore to an increase in primary production; on the other hand, downwelling events are associated with easterlies that lead to a marked decrease in phytoplankton and the overall chlorophyll concentration (García-Lafuente and Ruiz 2007, Navarro and 
Ruiz 2006). Furthermore, the alternation of mixing and stratification periods in the region affects the position of the nutricline and thus also regulates the primary production (Navarro et al. 2006). The area is characterized by a semi-diurnal tidal regime, with the tidal height ranging from $3.5 \mathrm{~m}$ at spring tide to $0.5 \mathrm{~m}$ at neap tide. The tidal regime also plays an important role in the studied area (García-Lafuente and Ruiz 2007).

Thus, the area is characterized by both physical and biological processes that could affect the inorganic carbon availability for primary producers. This could lead to shifts in species composition and ultimately influence both ecosystem regulation and biogeochemical cycling through variation in the biological carbon pump (Huertas et al. 2006).

\section{Field sampling}

The data reported in this work were collected during four cruises that took place from 17 to 28 June 2006 (Jun'06), from 19 to 30 November 2006 (Nov'06) and from 31 January to 9 February 2007 (Feb'07) on board the R/V Mytilus, and from 21 to 24 May 2007 (May'07) on board the R/V Ucádiz, thus an annual seasonal cycle from June 2006 to May 2007 was covered. A total of 63 stations located between 36.39 and $36.93^{\circ} \mathrm{N}$ and between 6.83 and $6.25^{\circ} \mathrm{W}$ were sampled, ranging from 8 to $95 \mathrm{~m}$ depth (Fig. 1). Except in May'07, nine extra stations off Guadalquivir Estuary and the Bay of Cádiz were sampled in the same conditions. At each station, surface $(\sim 3 \mathrm{~m}$ below the sea surface) and near-bottom ( $\sim \mathrm{m}$ above the seafloor) water samples were collected with Niskin bottles, which were mounted on a rosette-sampler coupled to a Seabird CTD equipped with a Seatech fluorometer and a Seabird thermosalinograph (SeaBird 43). Additional water samples were collected at other depths at various stations when unusual conditions were observed. Based on the physical and biological properties of the sampled area the study site was divided into three different zones for comparative purposes: Guadalquivir Estuary (GL), the Bay of Cádiz (BC) and the surface oceanic water (SOW).

\section{DOC and TDN measurements}

Samples were collected in $10 \mathrm{~mL}$ pre-combusted ampoules and were filtered through pre-combusted Whatman $\mathrm{GF} / \mathrm{F}$ filters of $47 \mathrm{~mm}$ diameter $(0.7 \mu \mathrm{m}$ nominal pore size). Samples were taken in duplicate, acidified by addition of $85 \% \mathrm{H}_{3} \mathrm{PO}_{4}(\mathrm{pH}<2)$, sealed and stored in the dark at $4^{\circ} \mathrm{C}$ in the laboratory. The Shimadzu instrument used in this study was the commercially available Model TOC-5000 analyzer with quartz combustion column in the vertical position filled with $1.2 \% \mathrm{Pt}$ silica pillow. In addition, the system performance was verified daily using standards produced by the Hansell Certified Reference Material (CRM) program. Three seawater CRM and three low carbon water (LCW) analyses were performed each analytical day. The nominal values provided by the Hansell Laboratory were 41-44 $\mu \mathrm{M}$ and $33 \mu \mathrm{M}$ for DOC and total dissolved nitrogen (TDN) respectively. The measured values were $42.5 \pm 0.9 \mu \mathrm{M}$ and $32.8 \pm 0.3 \mu \mathrm{M}$. The LCW values measured were $1.9 \pm 1.3$ $\mu \mathrm{M}$ (nominal $1-2 \mu \mathrm{M}$ ) and $0.3 \pm 0.1 \mu \mathrm{M}$ (nominal $0 \mu \mathrm{M}$ ) for DOC and TDN respectively.

\section{Inorganic carbon system determinations (DIC and NEP)}

At each station samples were collected to analyze TA and $\mathrm{pH}$. Analyses of the filtered samples were carried out on board. The $\mathrm{pH}$ was measured with a glass combined electrode (Methrom) calibrated using the buffer Tris/Tris- $\mathrm{HCl}$ (ionic strength $0.7 \mathrm{M}$ ) in the total $\mathrm{pH}$ scale with an accuracy of \pm 0.003 . TA was measured in $100 \mathrm{~mL}$ samples with potentiometric titration curves by means of the Gran Function. TA was measured using an automatic potentiometric titrator "Metrohm 794 analyzer", with a combination glass electrode, calibrated following the protocol described by Del Valls and Dickson (1998). The method has an accuracy of \pm 2 $\mu \mathrm{mol} \mathrm{kg} \mathrm{kg}^{-1}$. In order to check the accuracy of the $\mathrm{pH}$ and TA measurements, samples of $\mathrm{CO}_{2}$ reference material (CRM, batch 50, distributed by A.G. Dickson from Scripps Institution of Oceanography) were analyzed during the cruises.

The DIC was calculated from $\mathrm{pH}$ and TA using thermodynamic equations in seawater and the constants described by Mehrbach et al. (1973) refitted by Dickson and Millero (1987) for carbonate, and Dickson (1990) for sulphate. The calculated error for DIC was $\pm 2.6 \mu \mathrm{mol} \mathrm{kg} \mathrm{kg}^{-1}$.

The mean $\mathrm{CO}_{2}$ flux for each cruise was taken from Ribas-Ribas et al. (2011a) following the formula: $\mathrm{FCO}_{2}=\alpha \mathrm{k} \Delta f \mathrm{CO}_{2}$, where $\alpha$ is the solubility coefficient of $\mathrm{CO}_{2}$ (Weiss 1974), $\mathrm{k}$ is the gas transfer velocity of $\mathrm{CO}_{2}$ calculated using the equation given by Wanninkhof (1992), and $\triangle f \mathrm{CO}_{2}$ is the mean difference between the water and air $f \mathrm{CO}_{2}$. A negative value indicates airto-sea flux and a positive flux value represents the net $\mathrm{CO}_{2}$ exchange from the water body to the atmosphere.

The net ecosystem production (NEP, in mmol $\mathrm{C}$ $\mathrm{m}^{-2}$ day $^{-1}$ ) was calculated using the protocol shown in Ribas-Ribas et al. (2011b). In summary, NEP was computed from the temporal DIC variations from June 2006 to May 2007 according to the following equation:

$$
\mathrm{NEP}=\left[\left(\mathrm{DIC}_{1}-\mathrm{DIC}_{2}\right) \cdot \mathrm{d} / \Delta \mathrm{t}\right]-\mathrm{FCO}_{2}
$$

where $\mathrm{DIC}_{1}$ and $\mathrm{DIC}_{2}$ are the values in $\mathrm{mmol} \mathrm{m} \mathrm{m}^{-3}$ during two consecutive cruises, $\mathrm{FCO}_{2}$ in mmol $\mathrm{C} \mathrm{m}^{-2} \mathrm{~d}^{-1}$ is the mean $\mathrm{CO}_{2}$ flux for the two cruises (Ribas-Ribas et al. 2011a), $\Delta \mathrm{t}$ is the time interval in days between the two cruises, and $d$ is the mean depth of the area, $20 \mathrm{~m}$. If NEP is positive, an ecosystem is defined as autotrophic, i.e. when gross primary production $(\mathrm{P})$ exceeds community respiration $(\mathrm{R})$. 


\section{Total autotrophic and picophytoplankton biomass (Chlorophyll- $a$ and flow cytometry analysis)}

For the chlorophyll- $a$ analysis about $500 \mathrm{~mL}$ were filtered on board using Millipore filters (0.45 $\mu \mathrm{m}$ pore size), frozen at $-20^{\circ} \mathrm{C}$ and then analyzed in the laboratory by fluorimetry after extraction with 90\% acetone in the dark (Yentsch and Menzel 1963). Chlorophyll size-fractionation was also performed during the Feb'07 and May'07 cruises using a filtration column equipped with Whatman GF/F (i.e. $0.7 \mu \mathrm{m}$ pore size) and $20 \mu \mathrm{m}$ pore size nylon filters (Millipore). For picophytoplankton analysis, about $100 \mathrm{~mL}$ were collected in amber bottles and fixed in $1 \%$ glutaraldehyde (final concentration) (Marie et al. 2005). The samples were analyzed using a FACSCalibur (Becton-Dickinson) flow cytometer that was equipped with a blue argon-laser $(488 \mathrm{~nm})$ and a red diode laser $(635 \mathrm{~nm})$, four photomultipliers with bandpass filters (FL1 515-545, FL2 564-606 nm, FL3 >650 nm and FL4 $661 \mathrm{~nm}$ ) and detectors for the forward light scatter (FSC) and side scatter (SSC). A known volume of each sample was analyzed for cell abundance and characteristics and data were computed with CellQuest software (Beckton-Dickinson). The SSC signal was used as the cellular size indicator (Sobrino et al. 2004), and FL3, FL2 and FL4 were used as indicators of chlorophyll, phycoerytrin and phycocyanin contents respectively. However, in order to obtain comparative results, we used the approach that has been used in the area by other authors (Echevarría et al. 2009, Anfuso 2011). Cell abundance was transformed to carbon content ( $\mathrm{pgC}$ $\mathrm{mL}^{-1}$ ) according to DuRand et al. (2001), using the ratios 0.112 and $0.056 \mathrm{pgC}^{-1 l^{-1}}$ for Synechococcus and Procholorochoccus respectively. To analyze the relative contribution of picophytoplankton to the total autotrophic biomass, we converted chlorophyll- $a$ values to carbon biomass using the factor $18 \mu \mathrm{gC}$ $\mu \mathrm{g} \mathrm{Chl}{ }^{-1}$. This value was reported for coastal waters by Chiang et al. (2002) and fits well in the range proposed by Taylor et al. (1997).

\section{Dissolved oxygen determination and Apparent Oxygen Utilization}

DO samples were fixed in oceanographic Winkler bottles and stored in darkness for $24 \mathrm{~h}$, as described by Grasshoff et al. (1983), for later analysis by potentiometric titration (Metrohm 670 Titroprocessor). The Apparent Oxygen Utilization (AOU), defined as the deviation of oxygen from an $\mathrm{O}_{2}$ concentration in equilibrium with the atmosphere, was calculated with the Benson and Krause (1984) solubility equation. Such deviation typically occurs when biological activity acts to change the ambient concentration of oxygen, and it is mainly related to primary production (increase in $\mathrm{AOU}$ ) or respiration (decrease in $\mathrm{AOU})$.

\section{Suspended particulate matter and particulate organic carbon measurements}

For the assessment of the Suspended Particulate Matter (SPM) and the Particulate Organic Carbon (POC) $500 \mathrm{~mL}$ samples were filtered on board onto precombusted $\mathrm{GF} / \mathrm{F}$ filters that were immediately frozen at $-20^{\circ} \mathrm{C}$. Once at the laboratory, they were dried in an oven and weighted to calculate total SPM. Filters were completely rinsed of residual salt prior to drying. Subsequently they were ashed at $450^{\circ} \mathrm{C}$ in a muffle furnace for $4 \mathrm{~h}$ and once again weighted to calculate the inorganic particulates (Loring and Rantala 1991). Filters for POC were analyzed using a CHNS-932-LECO elemental analyzer after $\mathrm{Cr}_{2} \mathrm{O}_{3}$ and $\mathrm{AgCo}_{3} \mathrm{O}_{4}$ were catalyzed and segregated on a Haysep-Q-Column (Gordon 1969).

\section{Nutrient and DON calculation}

Samples for nutrients (nitrate, silicate and nitrite) were filtered on board through $0.45 \mu \mathrm{m}$ Millipore filters, immediately frozen at $-20^{\circ} \mathrm{C}$, and analyzed in the laboratory. Nutrients were determined by segmented flow analysis with Alpkem autoanalyzers, following Grasshoff et al. (1983).

The dissolved organic nitrogen (DON) concentration in the samples was obtained by subtracting the independently-measured $\mathrm{NO}_{3}{ }^{-}$and $\mathrm{NO}_{2}{ }^{-}$(Anfuso 2011) from TDN. We did not measure ammonium in the samples, and only subtracted nitrate and nitrite from the total dissolved nitrogen using a similar approach to that of Bates and Hansell (1999) and Suratman et al. (2010). Hence our DON actually includes ammonium. The analytical errors were estimated to be \pm 0.3 $\mu \mathrm{M}$ for TDN, $\pm 0.05 \mu \mathrm{M}$ for $\mathrm{NO}_{3}{ }^{-}$(Anfuso et al. 2010) and $\pm 0.02 \mu \mathrm{M}$ for $\mathrm{NO}_{2}{ }^{-}$(Anfuso, personal communication). As a consequence, the precision of the DON estimation was considered to be $\pm 0.3 \mu \mathrm{M}$.

\section{Statistical analysis}

Seasonal differences in hydrological and biogeochemical characteristics were analyzed using one-way analysis of variance (ANOVA), followed by the Bonferroni post hoc test (Statgraphics Centurion XVI.I). The threshold value for statistical difference was taken as $\mathrm{p}<0.05$.

Integrated total carbon biomass, dissolved inorganic carbon, dissolved organic carbon and particulate organic carbon were represented with Ocean Data View (ODV) (Schlitzer 2009) and were interpolated using the DIVA Gridding method.

\section{RESULTS}

Figure 2 shows the relationship between DIC and AOU, total carbon biomass, picophytoplankton biomass, nitrate+nitrite, silicate and SPM during the four cruises in the three studied areas. It should be pointed out that 


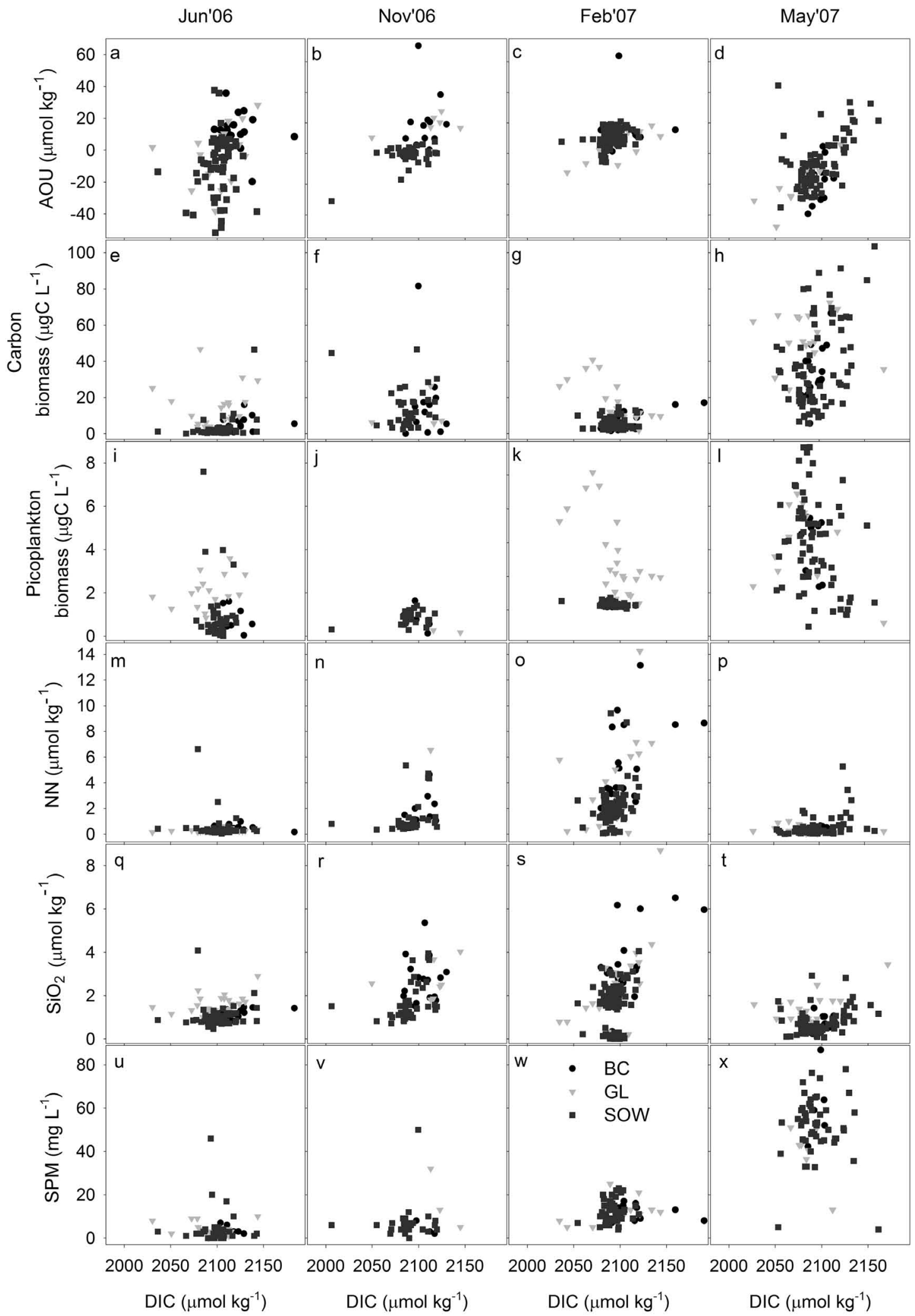

Fig. 2. - Property-property plots of dissolved inorganic carbon $\left(\mu \mathrm{mol} \mathrm{kg}{ }^{-1}\right)$ versus apparent oxygen utilization $\left(\mu \mathrm{mol} \mathrm{kg}^{-1}\right)$, total carbon

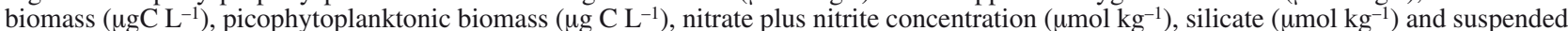
particulate matter ( $\left.\mathrm{mg} \mathrm{L}^{-1}\right)$. Data are divided into three sectors: Bay of Cádiz (black circles), Guadalquivir Estuary (gray triangles) and surface oceanic water (gray squares). The first column of the plots corresponds to Jun'06, the second one to Nov'06, the third one to Feb'07 and the last one to May'07. 
TABLE 1. - Minimum (min), maximum (max), mean (avg) values and standard deviation (sd) of salinity (S), temperature (T; $\left.{ }^{\circ} \mathrm{C}\right)$, apparent oxygen utilization ( $\mathrm{AOU} ; \mu \mathrm{mol} \mathrm{kg}{ }^{-1}$ ), dissolved inorganic carbon (DIC; $\left.\mu \mathrm{mol} \mathrm{kg}{ }^{-1}\right), \mathrm{CO}_{2}$ flux $\left(\mathrm{FCO}_{2} ; \mathrm{mmol} \mathrm{m}^{-2} \mathrm{~d}^{-1}\right.$ ), dissolved organic carbon (DOC; $\mu \mathrm{mol} \mathrm{kg}{ }^{-1}$ ), dissolved organic nitrogen $\left(\mathrm{DON} ; \mu \mathrm{mol} \mathrm{kg}{ }^{-1}\right)$, nitrate plus nitrite concentration $\left(\mathrm{NN} ; \mu \mathrm{mol} \mathrm{kg}^{-1}\right), \mathrm{silicate}\left(\mathrm{SiO}_{2} ; \mu \mathrm{mol} \mathrm{kg}{ }^{-1}\right)$, particulate organic carbon (POC; $\mu \mathrm{mol} \mathrm{kg}{ }^{-1}$ ), suspended particulate matter (SPM; mg L $\mathrm{L}^{-1}$ ), total chlorophyll- $a$ concentration (Total Chla; $\mu \mathrm{g}$

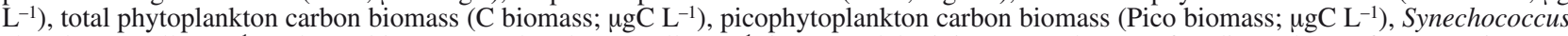
abundance (cells $\mathrm{mL}^{-1}$ ) and Prochlorococcus abundance (cells $\mathrm{mL}^{-1}$ ) in a) Guadalquivir Estuary, b) Bay of Cádiz, and c) surface oceanic water during the entire study period.

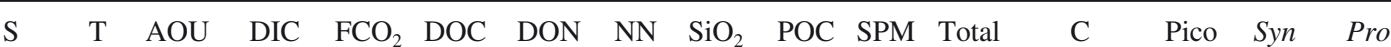 \\ Chla biomass biomass}

a) Guadalquivir Estuary

Jun'06

Min 36.

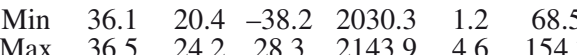

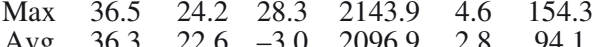

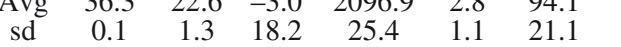

$\begin{array}{llllllll}\text { Nov'06 } & \text { Min } & 33.8 & 18.0 & -2.6 & 2049.6 & -1.7 & 61.8\end{array}$

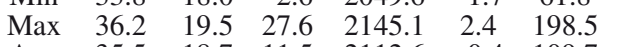

$\begin{array}{llllllll}\text { Avg } & 35.5 & 18.7 & 11.5 & 2112.6 & -0.4 & 109.7 & 11.7\end{array}$

sd 0.5

Feb'07

$\begin{array}{lllllll}\text { Min } & 33.2 & 12.6 & -12.2 & 2034.6 & -9.9 & 64.8\end{array}$

$\begin{array}{lllllll}\operatorname{Max} & 36.2 & 14.5 & 18.3 & 2205.1 & -0.7 & 148.9\end{array}$

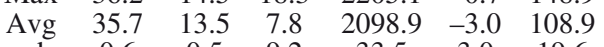

sd $\quad 0.6$

May'07

$\begin{array}{cccccccc}\text { Min } & 35.7 & 17.7 & -47.8 & 2027.2 & -3.6 & 75.7 & 5.5 \\ \text { Max } & 36.2 & 20.3 & 79.9 & 2171.3 & 0.5 & 185.2 & 13.8 \\ \text { Avg } & 36.0 & 19.0 & -15.3 & 2085.6 & -1.5 & 123.9 & \\ \text { sd } & 0.1 & 0.8 & 25.7 & 30.7 & 1.4 & 26.6 & \end{array}$

sd 0.1

b) Bay of Cádiz

\begin{tabular}{|c|c|c|c|c|c|c|c|c|c|c|c|c|c|c|c|c|c|}
\hline \multirow[t]{4}{*}{ Jun'06 } & Min & 36.3 & 19.3 & -19.7 & 2097.2 & 0.0 & 50.3 & 2.6 & 0.2 & 0.9 & 11.5 & 0 & 0.0 & 0.4 & 0.0 & 17 & 0 \\
\hline & Max & 36.7 & 22.5 & 35.8 & 2183.4 & 1.2 & 155.5 & 8.3 & 1.0 & 1.5 & 29.3 & 21 & 0.9 & 16.0 & 1.6 & 1585 & 14305 \\
\hline & Avg & 36.4 & 21.0 & 9.5 & 2118.8 & 0.6 & 103.5 & 4.8 & 0.4 & 1.2 & 17.5 & 6 & 0.2 & 3.3 & 0.7 & 559 & 6363 \\
\hline & $\mathrm{sd}$ & 0.1 & 0.9 & 11.0 & 18.3 & 0.3 & 26.2 & 1.4 & 0.2 & 0.2 & 5.5 & 7 & 0.2 & 3.8 & 0.5 & 621 & 4300 \\
\hline \multirow{4}{*}{ Nov'06 } & Min & 35.6 & 17.9 & -7.1 & 2083.9 & -0.7 & 54.1 & 2.4 & 0.7 & 1.3 & 1.0 & 2 & 0.0 & 0.0 & 0.1 & 502 & 840 \\
\hline & Max & 36.4 & 19.6 & 70.3 & 2130.1 & 3.2 & 178.2 & 11.3 & 4.8 & 5. & 4.2 & 8 & 4. & 81.5 & 1.6 & 12850 & 8190 \\
\hline & Avg & 36.2 & 19.0 & 12.8 & 2104.8 & 0.8 & 90.7 & 6.3 & 1.9 & 2.6 & 2. & 5 & 0.9 & 15.4 & 0.9 & 4906 & 5317 \\
\hline & sd & 0.2 & 0.5 & 15.4 & 14.1 & 1.3 & 29.9 & 2.5 & 1.2 & 1.0 & 1.3 & 2 & 0.9 & 16.8 & 0.5 & 3931 & 2443 \\
\hline \multirow[t]{4}{*}{ Feb'07 } & Min & 34.0 & 12.0 & 1.5 & 2079.4 & -7.4 & 43.2 & 0. & 1.3 & 0. & 5.5 & 7 & 0.1 & 1. & 0.9 & 8822 & 2642 \\
\hline & Max & 36.4 & 15.4 & 102.9 & 2190.6 & 0.0 & 130.8 & 18.3 & 13.5 & 6.7 & 43.3 & 17 & 0. & 17.1 & 1.6 & 18547 & 6522 \\
\hline & Avg & 35.9 & 14.2 & 17.3 & 2103.1 & -2.5 & 85. & 3.8 & 4.2 & 2.8 & 17.7 & 12 & 0. & 5.7 & 1.2 & 12910 & 3998 \\
\hline & $\mathrm{s}$ & 0.7 & 0.9 & 19.7 & 23.2 & 2.7 & 25.7 & 4.0 & 3.2 & 1.8 & 12.2 & 3 & 0.2 & 4.4 & 0.2 & 3082 & 1257 \\
\hline \multirow{4}{*}{ May'07 } & Min & 36.1 & 16.9 & -39.4 & 2080.3 & -1.2 & 68. & 8. & 0. & 0.2 & 15 & 39 & 0. & 5 & 2.3 & 0 & 14150 \\
\hline & Max & 36.2 & 19.0 & 5.1 & 2113.0 & 0.9 & 170.1 & 15.5 & 0.7 & 1.5 & 47.6 & 87 & 3. & 66.5 & 5.5 & 13685 & 48975 \\
\hline & Avg & 36.1 & 17.9 & -14.1 & 2095.9 & -0.4 & 117.6 & 10.5 & 0.3 & 0.7 & 24.8 & 57 & 1.8 & 32.7 & 4.2 & 4110 & 35585 \\
\hline & $\mathrm{sd}$ & 0.0 & 0.5 & 12.7 & 9.2 & 0.7 & 28.2 & 2.4 & 0.2 & 0.4 & 11.8 & 17 & 0.8 & 14.9 & 1.2 & 4572 & 12254 \\
\hline
\end{tabular}

$\begin{array}{cccc}1.5 & 0.5 & 178 & 4732 \\ 46.7 & 3.6 & 667 & 31780 \\ 12.9 & 2.0 & 420 & 17480 \\ 11.2 & 0.8 & 238 & 7303 \\ & & & \\ 3.2 & 0.1 & 172 & 702 \\ 76.1 & 0.3 & 678 & 2527 \\ 19.6 & 0.2 & 366 & 1395 \\ 16.4 & 0.1 & 185 & 745 \\ & & & \\ 1.9 & 0.3 & 452 & 1193 \\ 40.8 & 1.9 & 22460 & 9300 \\ 15.6 & 1.0 & 7969 & 5028 \\ 11.3 & 0.5 & 6897 & 2593 \\ & & & \\ 24.4 & 0.6 & 0 & 4318 \\ 72.4 & 6.6 & 18678 & 54372 \\ 51.4 & 4.3 & 4698 & 36299 \\ 14.1 & 1.8 & 6940 & 15847\end{array}$

c) Surface Oceanic Water

\begin{tabular}{|c|c|c|c|c|c|c|c|c|c|c|c|c|c|c|c|c|c|}
\hline Jun'06 & $\begin{array}{c}\text { Min } \\
\text { Max } \\
\text { Avg } \\
\text { sd }\end{array}$ & $\begin{array}{c}36.1 \\
36.5 \\
36.4 \\
0.1\end{array}$ & $\begin{array}{c}19.1 \\
23.6 \\
21.6 \\
1.0\end{array}$ & $\begin{array}{c}-51.8 \\
37.6 \\
-9.4 \\
18.1\end{array}$ & $\begin{array}{c}2036.1 \\
2142.9 \\
2102.1 \\
15.8\end{array}$ & $\begin{array}{c}-0.2 \\
5.4 \\
1.3 \\
1.3\end{array}$ & $\begin{array}{l}64.1 \\
169 \\
94.2 \\
21.6\end{array}$ & $\begin{array}{c}2.7 \\
11.2 \\
5.1 \\
1.7\end{array}$ & $\begin{array}{l}0.0 \\
6.8 \\
0.4 \\
0.8\end{array}$ & $\begin{array}{l}0.5 \\
4.2 \\
1.0 \\
0.4\end{array}$ & $\begin{array}{c}3.6 \\
36.3 \\
12.2 \\
6.6\end{array}$ & $\begin{array}{c}0 \\
46 \\
4 \\
8\end{array}$ & $\begin{array}{l}0.0 \\
2.6 \\
0.1 \\
0.3\end{array}$ & $\begin{array}{c}0.1 \\
46.5 \\
2.3 \\
5.4\end{array}$ & $\begin{array}{l}0.0 \\
7.6 \\
0.9 \\
1.3\end{array}$ & $\begin{array}{l}2942 \\
9360 \\
5186 \\
3619\end{array}$ & $\begin{array}{c}100 \\
66197 \\
8000 \\
11206\end{array}$ \\
\hline Nov’06 & $\begin{array}{c}\text { Min } \\
\text { Max } \\
\text { Avg } \\
\text { sd }\end{array}$ & $\begin{array}{c}35.0 \\
36.5 \\
36.2 \\
0.3\end{array}$ & $\begin{array}{c}18.6 \\
19.9 \\
19.3 \\
0.4\end{array}$ & $\begin{array}{c}-31 \\
60.8 \\
3.0 \\
9.7\end{array}$ & $\begin{array}{c}2006.2 \\
2119.8 \\
2088.9 \\
19.2\end{array}$ & $\begin{array}{c}-7.8 \\
0.1 \\
-0.9 \\
1.7\end{array}$ & $\begin{array}{c}57.8 \\
135.7 \\
83.3 \\
18.2\end{array}$ & $\begin{array}{c}0.1 \\
19.2 \\
7.4 \\
2.9\end{array}$ & $\begin{array}{c}0.2 \\
10.1 \\
1.1 \\
1.5\end{array}$ & $\begin{array}{l}0.7 \\
4.1 \\
1.5 \\
0.7\end{array}$ & $\begin{array}{l}0.9 \\
6.1 \\
2.8 \\
1.0\end{array}$ & $\begin{array}{c}0 \\
50 \\
15 \\
14\end{array}$ & $\begin{array}{c}0 \\
2.6 \\
0.6 \\
0.5\end{array}$ & $\begin{array}{c}0.4 \\
46.5 \\
10.8 \\
9.1\end{array}$ & $\begin{array}{l}0.1 \\
1.9 \\
0.7 \\
0.4\end{array}$ & $\begin{array}{c}207 \\
17612 \\
4464 \\
3493\end{array}$ & $\begin{array}{c}1013 \\
11778 \\
4268 \\
2563\end{array}$ \\
\hline Feb'07 & $\begin{array}{c}\text { Min } \\
\text { Max } \\
\text { Avg } \\
\text { sd }\end{array}$ & $\begin{array}{c}35.8 \\
36.4 \\
36.3 \\
0.1\end{array}$ & $\begin{array}{c}13.5 \\
16.0 \\
15.0 \\
0.6\end{array}$ & $\begin{array}{c}-5.5 \\
21.0 \\
10.9 \\
5.4\end{array}$ & $\begin{array}{c}2036.8 \\
2120.3 \\
2092.0 \\
12.2\end{array}$ & $\begin{array}{c}-7.8 \\
0.2 \\
-1.6 \\
1.6\end{array}$ & $\begin{array}{c}42.1 \\
158.7 \\
85.5 \\
25.9\end{array}$ & $\begin{array}{c}0.3 \\
11.3 \\
4.0 \\
2.6\end{array}$ & $\begin{array}{l}0.1 \\
9.7 \\
2.2 \\
1.4\end{array}$ & $\begin{array}{l}0.0 \\
4.2 \\
1.7 \\
1.0\end{array}$ & $\begin{array}{c}0.5 \\
62.8 \\
18.2 \\
11.4\end{array}$ & $\begin{array}{c}4 \\
23 \\
12 \\
5\end{array}$ & $\begin{array}{l}0.0 \\
0.8 \\
0.3 \\
0.2\end{array}$ & $\begin{array}{c}0.6 \\
14.7 \\
5.6 \\
2.8\end{array}$ & $\begin{array}{l}0.5 \\
3.6 \\
1.7 \\
0.6\end{array}$ & $\begin{array}{c}5873 \\
26478 \\
15859 \\
4815\end{array}$ & $\begin{array}{c}0 \\
20668 \\
7061 \\
4046\end{array}$ \\
\hline May’07 & $\begin{array}{c}\text { Min } \\
\text { Max } \\
\text { Avg } \\
\text { sd }\end{array}$ & $\begin{array}{c}35.8 \\
36.2 \\
36.1 \\
0.1\end{array}$ & $\begin{array}{c}15.5 \\
19.9 \\
17.7 \\
1.0\end{array}$ & $\begin{array}{c}-35.1 \\
64.1 \\
-5.8 \\
17.7\end{array}$ & $\begin{array}{c}2053.2 \\
2161.2 \\
2096.1 \\
22.2\end{array}$ & $\begin{array}{c}-2.1 \\
0.0 \\
-1.0 \\
0.5\end{array}$ & $\begin{array}{c}64.4 \\
153.3 \\
101 \\
20.3\end{array}$ & $\begin{array}{c}1.0 \\
19.8 \\
8.5 \\
2.9\end{array}$ & $\begin{array}{l}0.0 \\
5.4 \\
0.5 \\
0.8\end{array}$ & $\begin{array}{l}0.1 \\
3.8 \\
0.8 \\
0.6\end{array}$ & $\begin{array}{c}3.4 \\
64.6 \\
29.1 \\
13.0\end{array}$ & $\begin{array}{c}4 \\
87 \\
54 \\
16\end{array}$ & $\begin{array}{l}0.3 \\
5.7 \\
2.0 \\
1.3\end{array}$ & $\begin{array}{c}5.9 \\
102.5 \\
36.7 \\
23.0\end{array}$ & $\begin{array}{l}0.4 \\
8.7 \\
4.2 \\
2.1\end{array}$ & $\begin{array}{c}0 \\
22233 \\
5137 \\
6722\end{array}$ & $\begin{array}{c}0 \\
77937 \\
34582 \\
19606\end{array}$ \\
\hline
\end{tabular}




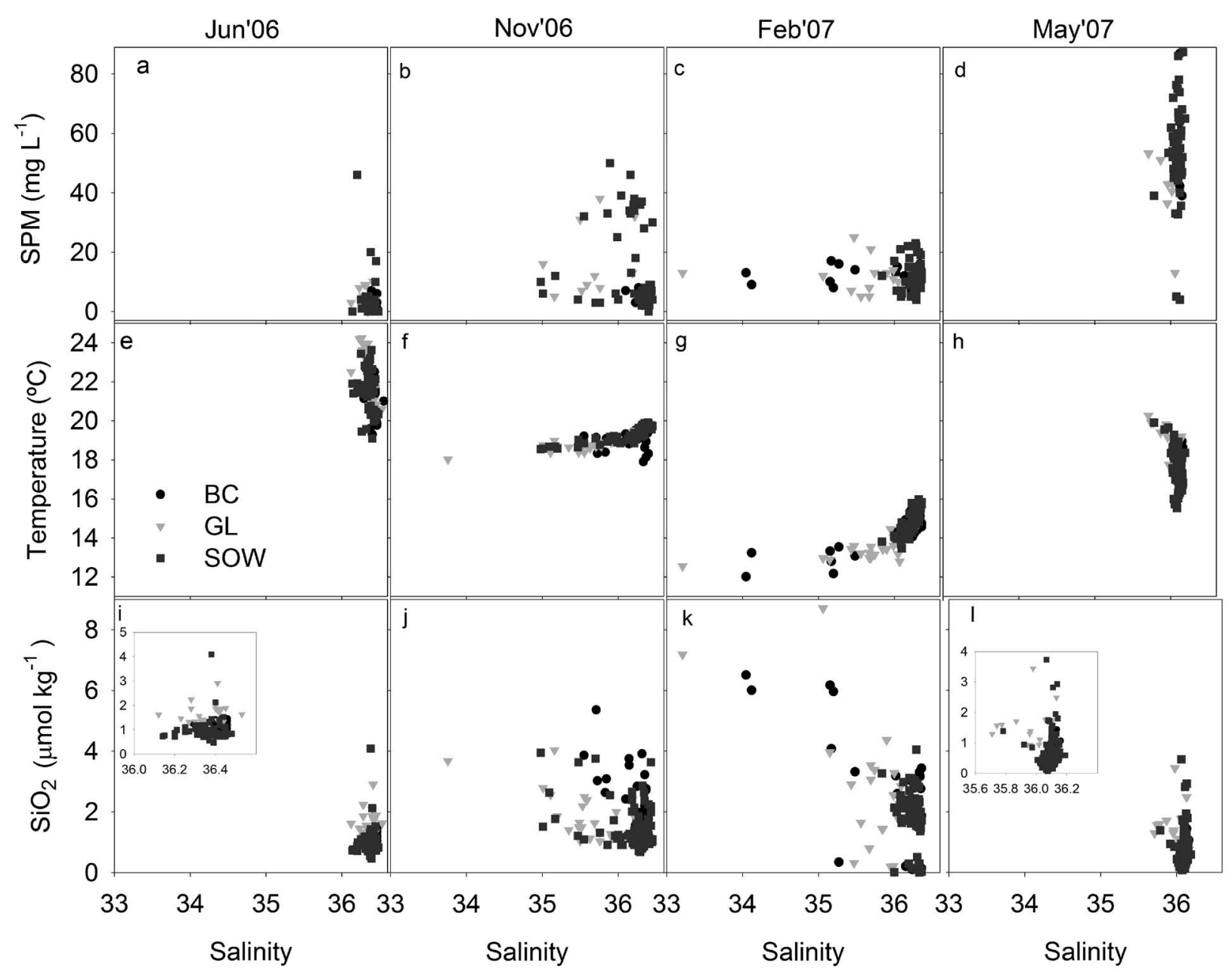

Fig. 3. - Mixing diagrams of suspended particulate matter $\left(\mathrm{mg} \mathrm{L}^{-1}\right)$, temperature $\left({ }^{\circ} \mathrm{C}\right)$ and silicate $\left(\mu \mathrm{mol} \mathrm{kg}^{-1}\right)$. The inset plots in $i$ and $l$ are a zoom of the main figures. Data are divided into three sectors: Bay of Cádiz (black circles), Guadalquivir Estuary (gray triangles) and surface oceanic water (gray squares).

there was a good correlation between AOU and DIC in all cruises except in Jun'06 $\left(\mathrm{r}^{2}=0.23, \mathrm{n}=66\right.$, Nov'06; $\mathrm{r}^{2}=0.23, \mathrm{n}=139$, Feb'07; $\mathrm{r}^{2}=0.39 ; \mathrm{n}=113$, May'07). However, total carbon biomass (Fig. 2e, h) and picophytoplanktonic biomass (Fig. 2i, l) both showed differences between summer and spring. During Jun'06 there was less picophytoplanktonic biomass than in May'07 (Table 1). Conversely, the total carbon biomass had values close to 0 off the $\mathrm{BC}$ and $\mathrm{SOW}$ while the values were higher off the GL (Fig. 2e; Table 1). In contrast, the mean picophytoplanktonic biomass was the highest during May'07 (Fig. 21; Table 1) as well as the total carbon biomass values (Fig. 2h; Table 1). Except for Feb'07, nitrate and nitrite concentrations were close to $0 \mu \mathrm{mol}$ $\mathrm{L}^{-1}$ in all the regions (Fig. $2 \mathrm{~m}, \mathrm{p}$; Table 1).

The mixing diagram of suspended particulate matter, temperature and silicate are plotted in Figure 3 for the four seasons and the three defined area. Considerable amounts of SPM were found in all seasons, particularly in May'07 (Table 1). Finally, the silicate concentration was also higher in Nov'06 and Feb'07 in association with river discharge (Table 1).

\section{Structure of the phytoplankton community}

Average chlorophyll- $a$ values from the three areas decreased from $2.13 \pm 1.20 \mu \mathrm{g} \mathrm{L}^{-1}$ in May'07 to $0.73 \pm 0.70 \mu \mathrm{g} \mathrm{L}^{-1}$ in Nov'06, $0.41 \pm 0.37 \mu \mathrm{g} \mathrm{L}^{-1}$ in Feb'07 and finally $0.25 \pm 0.43 \mu \mathrm{g} \mathrm{L}^{-1}$ in Jun'06. Maximum levels were found during May'07 (Table 1).

Within the picophytoplankton composition, the overall Synechococcus corresponded to $27 \%$ of the total picophytoplankton cells measured, whereas Prochlorococcus comprised $72 \%$. Prochlorococcus abundance was weakly correlated with the Synechococcus population $\left(\mathrm{r}^{2}=0.06\right)$. The relation between the fraction of picophytoplankton and the total autotrophic biomass is shown in Figure 4 for the four seasons and the three areas. In general, the samples with low chlorophyll- $a$ values showed a high percentage of chlorophyll- $a$ from small picophytoplankton cells, whereas in the samples with a higher chlorophyll- $a$ concentration, the small phytoplankton comprised $<10 \%$ of the total autotrophic biomass. 

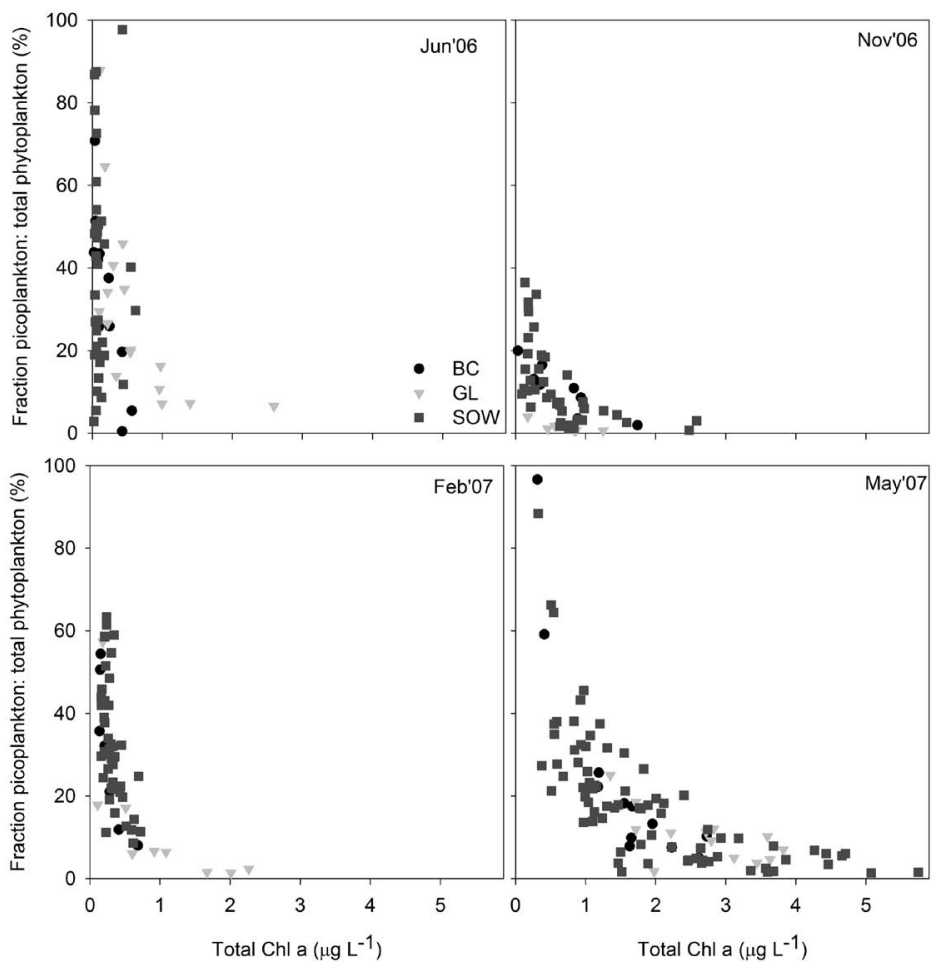

Fig. 4. - The fraction of autotrophic picoplankton to total phytoplankton carbon biomass as percentages (using conversions shown in the Materials and Methods section) with respect to the total chlorophyll- $a$ concentration $\left(\mu \mathrm{g} \mathrm{L}^{-1}\right)$. Data are divided into three sectors: Bay of Cádiz (black circles), Guadalquivir Estuary (gray triangles) and surface oceanic water (gray squares).
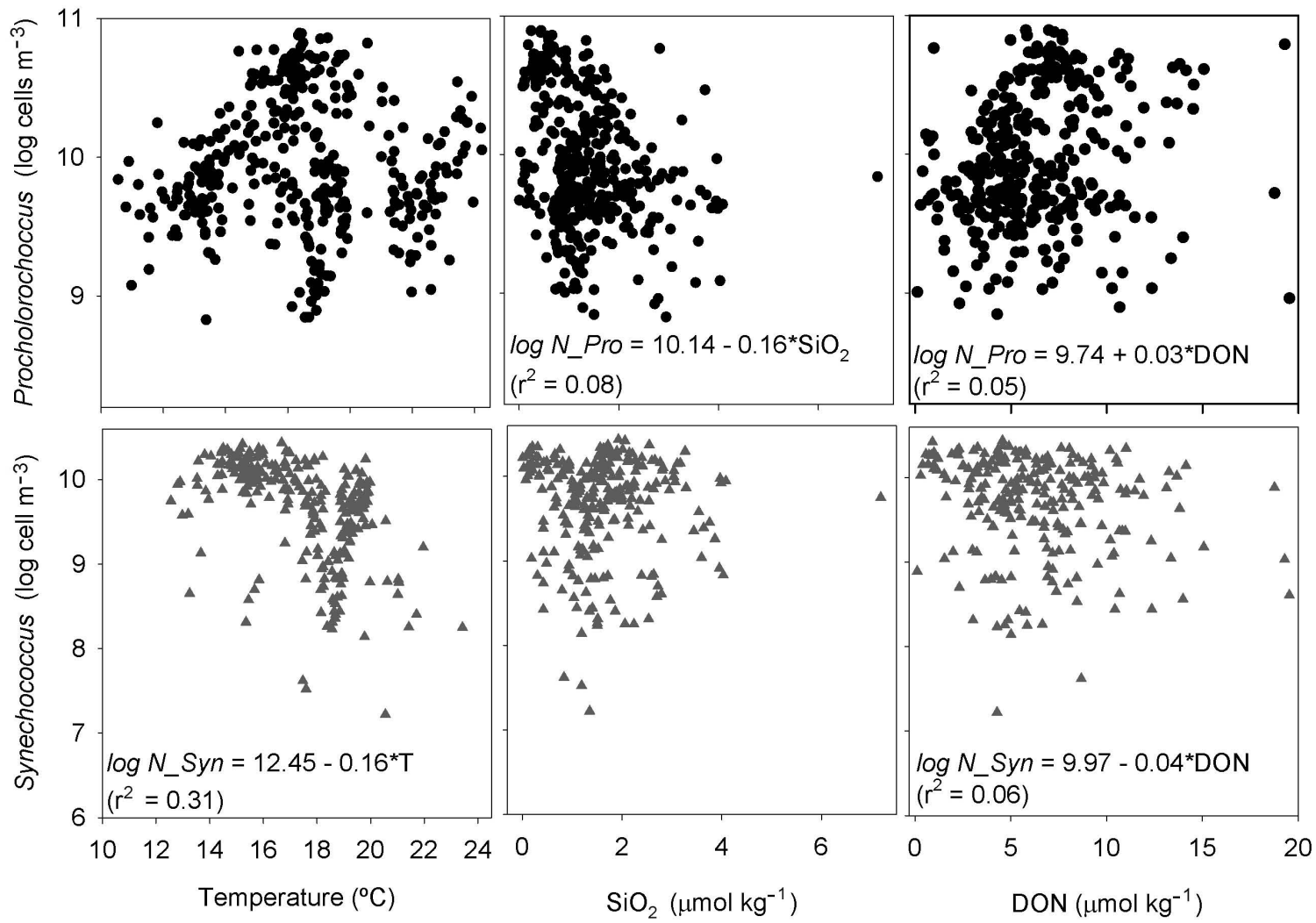

Fig. 5. - Relationship between Prochlorochoccus (black circles) and Synechococcus (gray triangles) abundance (log cell $\mathrm{m}^{-3}$ ) and temperature $\left({ }^{\circ} \mathrm{C}\right)$, silicate $\left(\mu \mathrm{mol} \mathrm{kg} \mathrm{kg}^{-1}\right)$ and dissolved organic nitrogen $(\mu \mathrm{mol} \mathrm{kg}-1)$ concentrations. The equations for the statistically significant linear regressions are shown. 

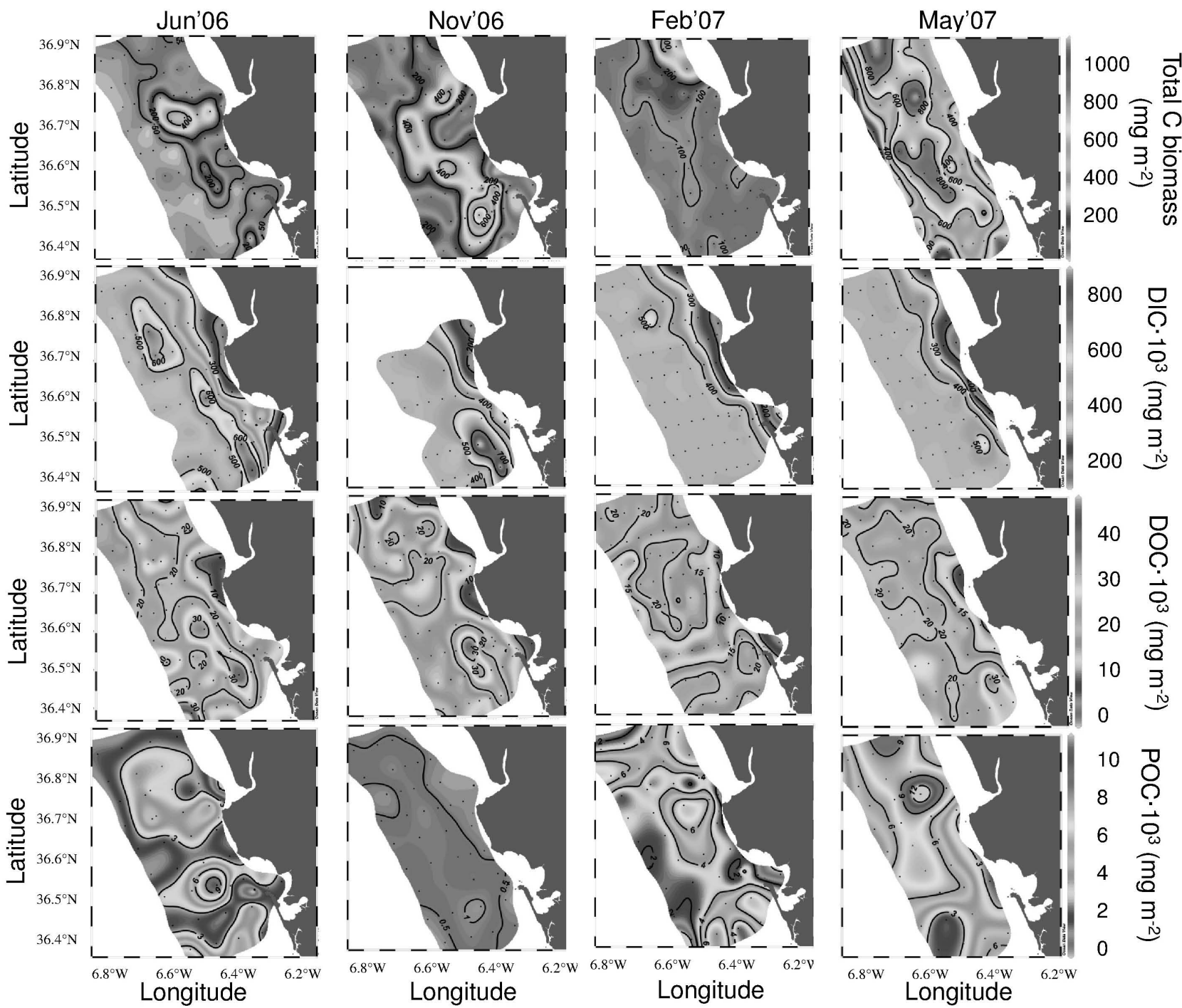

Fig. 6. - Contour plot showing the integrated total carbon biomass, dissolved inorganic carbon, dissolved organic carbon and particulate organic carbon (all in $\mathrm{mg} \mathrm{m}^{-2}$ ) of the continental shelf of the Gulf of Cádiz.

Among the different parameters measured, temperature, silicate and dissolved organic nitrogen concentrations seemed to influence Procholorochoccus and Synechococcus abundance (Fig. 5). The Synechococcus population density showed an inverse linear regression with temperature: $\log$ N_Syn $=12.45-0.16 \cdot t$ $\left(r^{2}=0.31, n=209\right)$. We were expecting a positive linear regression between the Prochlorochoccus population density and temperature but this was statistically not significant $(\mathrm{p}=0.55, \mathrm{n}=317)$. However, when the silicate concentration increased, Prochlorochoccus abundance decreased, as shown in the regression: $\log$ N_Pro $=10.14-0.16 \cdot \mathrm{SiO}_{2}\left(\mathrm{r}^{2}=0.08, \mathrm{n}=310\right)$. This pattern was not observed in Synechococcus. Finally, both abundances showed small but significant correlations with DON. However, while Prochlorochoccus slightly increased with an increase in DON, Synechococcus did the opposite, decreasing in abundance with the increase in DON concentration (Fig. 5).

\section{Spatial and seasonal distribution of carbon system parameters}

Figure 6 shows the total carbon biomass, dissolved inorganic carbon, dissolved organic carbon and particulate organic carbon integrated to $25 \mathrm{~m}$ depth for the four seasons. The integrated total carbon biomass showed a dome-type spatial distribution during most of the year, except in winter. Carbon biomass was high towards the central area and was in general lower in the SOW than GL or BC (Fig. 6). A local maximum of total carbon biomass during Nov'06 off the Bay of Cádiz coincided with a maximum in DIC, DOC and POC in the same area. Integrated DIC decreased onshore in the four seasons, especially near the mouth of the Guadalquivir Estuary. Integrated DOC showed a homogenous distribution, with a maximum off the Bay of Cádiz in all cruises except in Feb'07 and a minimum off the Guadalquivir Estuary. Integrated POC showed 


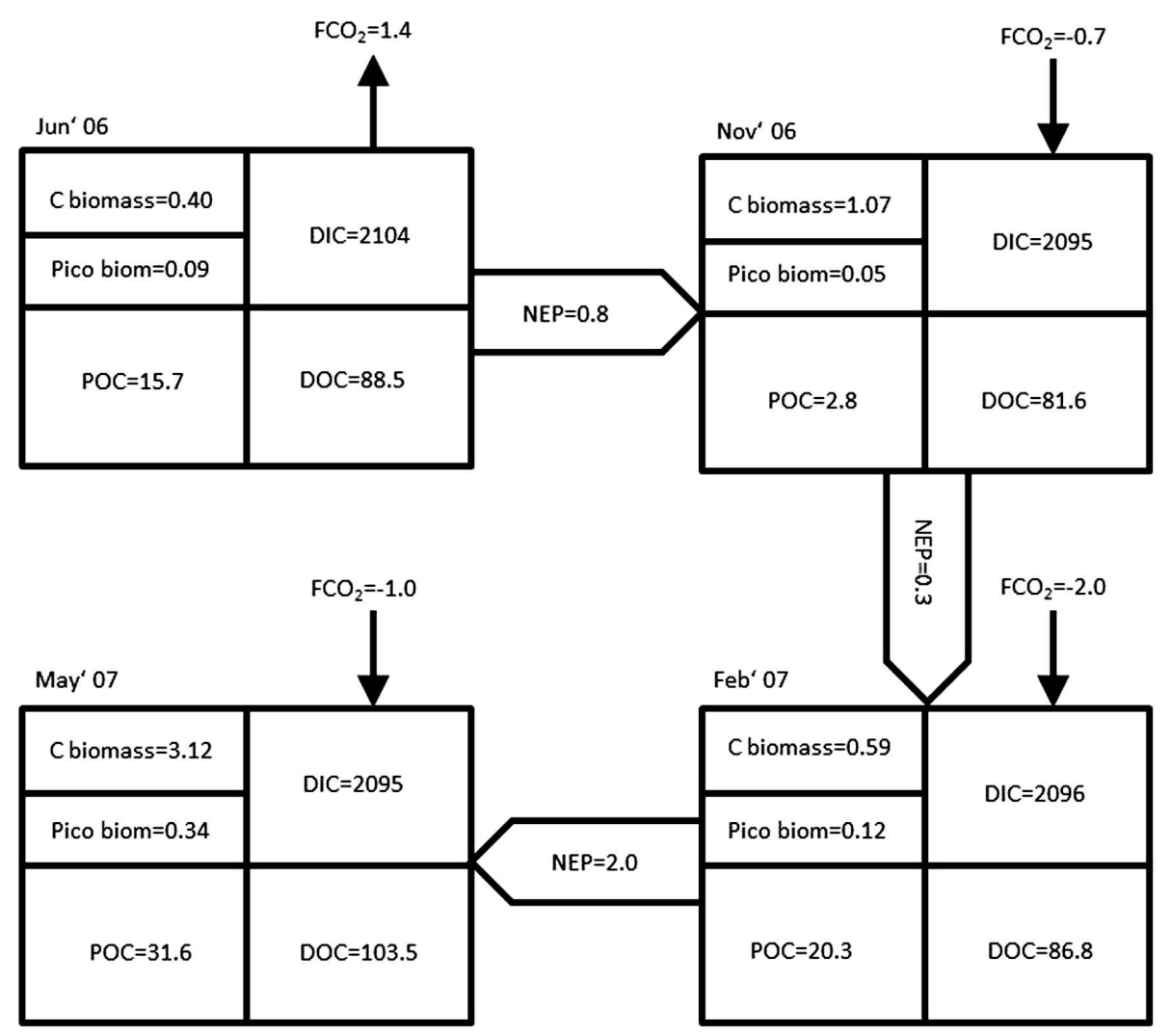

Fig. 7. - Schematic diagram showing the carbon budget for a box model of the continental shelf of the Gulf of Cádiz. Each box represents

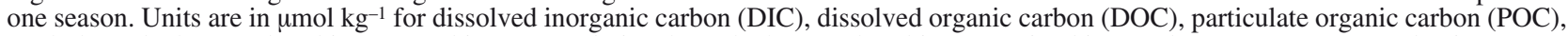
total phytoplankton carbon biomass (C biomass) and picophytoplankton carbon biomass (Pico biom). The net ecosystem production (NEP) and air-sea $\mathrm{CO}_{2}$ flux $\left(\mathrm{FCO}_{2}\right)$ are in $\mathrm{mmol} \mathrm{m} \mathrm{m}^{-2} \mathrm{~d}^{-1}$. A negative $\mathrm{FCO}_{2}$ value indicates air-to-sea flux and a positive flux value represents the net $\mathrm{CO}_{2}$ exchange from the water body to the atmosphere.

low values during Nov'06 and high during May'07. Off the Guadalquivir Estuary a maximum was detected in May'07, also coinciding with an integrated total C biomass maximum.

Figure 7 represents the schematic box diagram of the carbon budget for the four seasons. From Jun'06 to Nov'06, the total carbon biomass increased by 2.7 while the picophytoplankton was halved and POC decreased by five times. DIC and DOC decreased slightly. As shown in Figure 5 with the decrease in the picophytoplankton percentage, although the total carbon biomass in Nov'06 was more than twice the value in Jun'06, the picophytoplankton biomass was almost half. According to these calculations, bigger sized phytoplankton increased by more than three times. NEP was weakly positive in agreement with the increase in carbon biomass and the system shift from being a source to being a sink between these two seasons. From Nov'06 to Feb'07, the total carbon biomass was halved while the picophytoplankton biomass and POC increased by 2.4 and 7.3 times respectively, DOC increased slightly and DIC remained constant. The net ecosystem production (NEP) was weakly positive, probably due to the high $\mathrm{CO}_{2}$ flux from air to sea. Finally, from Feb'07 to May'07, all the carbon reservoirs greatly increased except the DIC. The NEP value was the highest of the year and the area behaves as a sink of $\mathrm{CO}_{2}$. Regarding seasonal temperature values, the mean carbon biomass varied significantly between Jun'06 and Feb'07, the seasons in which the highest and the lowest temperature values were observed $(<0.4 \mu \mathrm{mol}$ $\mathrm{kg}^{-1}$ ), and Nov'06 and May'07, the template seasons $\left(>1.1 \mu \mathrm{mol} \mathrm{kg} \mathrm{kg}^{-1}\right)$.

\section{DISCUSSION}

\section{Picophytoplankton abundance vs temperature}

T-S diagrams (Fig. 3f, g) clearly show the influence of freshwater during Nov'06 and Feb'07 and the lower temperature in Feb'07, which could affect the phytoplankton community.

Our results show that the integrated abundance of Synechococcus was inversely related to the average surface temperature, with low temperature values in Feb'07 and high values in Jun'06, and suggest that the seasonal variation of the Synechococcus population was driven by the seasonal fluctuation in temperature. There are some other studies that confirm a positive relationship between temperature and Synechococcus growth rates, abundance and biomass, with high values in summer compared to the rest of the year (Agawin $e t$ 
al. 1998). However, some authors did not find any coherent relationship between population abundance and temperature (Worden et al. 2004). Our results indicate that other factors such as advection or heavy grazing, might account for the absence of noticeable Synechococcus populations in Jun'06 in our study (Worden et al. 2004). We hypothesize that Synechococcus growth may not have exceeded the grazing capacity of its predator and this explains its absence in Jun'06, even though it played an important role in the carbon cycle by introducing carbon into the food web. It has been described that protist grazers may effectively remove the entire daily production of Synechococcus in the NW Mediterranean (Mura et al. 1996, Agawin and Agustí 1997), thereby maintaining a uniform abundance. On the contrary, Prochlorococcus did not show a statistically significant relationship with temperature.

\section{Picophytoplankton abundance vs nitrogen concentrations}

The results show that nutrient river inputs increased the total carbon biomass values at the same time that DIC decreased during Jun'06. During Feb'07 and May'07, river discharge and water column mixing were higher and so nutrients were more abundant (Fig. $2 \mathrm{n}, \mathrm{o}$ ). However, total carbon biomass values were not as high as we expected. Primary production could have been limited by light due to high suspended particular matter (Fig. 2v, w, x and 3b, c, d) or by temperature (Fig. 3g) since a minimum temperature value was observed in a nearby area (Navarro et al. 2006, RibasRibas et al. 2011c).

Maximum chlorophyll- $a$ values were found during May'07 (Table 1) due to a high nutrient consumption (Anfuso 2011). In Feb'07 and May'07, the chlorophyll$a$ concentration was higher in the smaller size fraction $(0.7 \mu \mathrm{m}$ pore size filter) than in the bigger size fraction (20 $\mu \mathrm{m}$ pore size filter), which represented $21 \%$ and $5 \%$ of the total autotrophic biomass respectively.

Our results show that Synechococcus and Prochlorococcus are efficient at using nutrients, exhibiting a capacity for near-maximal growth down to available DIN levels of $0.02 \mu \mathrm{M}$ or less. Like in this study, Chiang et al. (2002) did not observe a good relationship between Synechococcus abundance and other environmental factors, such as nitrate or light. Importantly, even slight or ephemeral increases in DIN concentrations to levels in the order of $0.1 \mu \mathrm{M}$, as would occur during a sediment resuspension event (Ribas-Ribas et al. 2011d), in a dispersed river plume or after upwelling are sufficient to support maximal or near-maximal growth of these important phytoplankton species (Furnas et al. 2005). Continued growth of phytoplankton can only be sustained through ongoing recycling and mineralization of organic nitrogen in biomass, detritus, and dissolved organic form (DON) (Furnas et al. 2005). Synechococcus are capable of using nitrate and ammonia, whereas Prochlorococcus is reported to use organic nitrogen in the natural environment (Zubkov et al. 2003, García-Fernández et al. 2004). The increase in Prochlorococcus abundance could be explained by the increasing DON concentration (Fig. 5), while the opposite was found for Synechococcus. Thus, when Synechococcus competes for macronutrients such as $\mathrm{NO}_{3}{ }^{-}$, Prochlorococcus relies on its ability to take up organic nitrogen compounds at high rates. Some other authors found that Prochlorococcus numbers were higher during and after summer when the dynamics of the system are thought to be dominated in part by recycled nutrients (Furnas et al. 2005).

These results show that during May'07 and Jun'06, the nutrients were already used. Phytoplankton were still active in May'07 but they were entering a senescent state in Jun'06.

\section{Picophytoplankton abundance vs silicate concentrations}

Silicate is a limiting nutrient for diatoms, which characteristically form blooms following nutrient input events. Importantly, though, silicate is not required for Synechococcus and Prochlorococcus growth (Furnas et al. 2005). However, our results show that Prochlorococcus abundance increased when silicates decreased while Synecoccocus abundance increased when the temperature decreased (Fig. 5). Even though the relation between Prochlorococcus abundance and silicate was weak, it is important to point out that this relation suggests that picophytoplankton growth could be limited by diatom growth. Thus when diatoms dominated due to the presence of non-limiting silicate concentrations there were less available resources for picophytoplankton. In the studied area Prochlorococcus disappeared when diatoms competed during the increase in silicate in Nov'07 (Kristiansen et al. 2001, Mann and Lazier 2006) and started to bloom during May'07 when silicate became a limiting factor for diatoms. On the other hand, Synechococcus was predominant in Feb'07 and decreased when the temperature increased, probably due to Prochlorococcus competition. Within these scenarios, big sized phytoplankton such as diatoms were probably predominant during Jun'06 and Nov'06, when high chlorophyll- $a$ concentrations were found off the Guadalquivir Estuary, but there were no correspondence with picophytoplankton biomass. The percentages of $\mathrm{C}$ biomass that were picoplankton biomass were always lower off the Guadalquivir Estuary than in the surface oceanic water. This situation does not seem typical in marine ecology, which normally shows a seasonal shift from communities dominated by diatoms in winter to communities dominated by smaller autotrophs in nutrient-poor waters in summer (Mura et al. 1996). The contradictory results observed in our study could be explained by atypical events recorded just before the Jun'06 cruise. Strong rainfall was recorded in the meteorological stations in the nearby area that could have increased the silicate concentration, 
which was immediately consumed by big phytoplankton. The Guadalquivir River was probably the main source of silicate over the year. Prieto et al. (2009) also described the response of the pelagic ecosystem to a high rainfall event that affected river discharge.

\section{Different pieces of the coastal carbon budget}

First of all, it is important to point out, as $\mathrm{Li}$ et al. (2006) did, that a huge difference exists between biomass and abundance, i.e. the picophytoplankton can be really abundant while the biomass can be less significant due to their small size, or the other way round, big phytoplankton can contribute more to the total autotrophic biomass even if they are less abundant. This could be the case in Jun'06 off the Guadalquivir Estuary, where a maximum of total carbon biomass did not correspond with a maximum in picophytoplankton biomass, probably due to a diatoms bloom caused by an increase in silicate after the heavy rain. The picoplankton biomass represents $17 \%$ of the total C biomass off the Guadalquivir Estuary, and 39\% in the surface oceanic water. It is also important to consider the uncertainty over carbon conversion factors (DuRand et al. 2001, Worden et al. 2004). Secondly, there are some uncertainties in the estimation of the $\mathrm{C}$ budget due to limitations in the experimental approach. For example, for the $\mathrm{FCO}_{2}$ an error of $\pm 3 \mu \mathrm{atm}$ for the $f \mathrm{CO}_{2}{ }^{\text {sw }}$ has been reported (Ribas-Ribas et al. 2011a) plus the choice of gas transfer velocity and the location of $f \mathrm{CO}_{2}{ }^{\text {atm }}$ data. Again Ribas-Ribas et al. (2011b) discussed the different NEP values obtained by different approaches; Ribas-Ribas et al. (2011b,d) still estimated DOC and DIC uncertainties to be $0.9 \mu \mathrm{mol} \mathrm{kg}{ }^{-1}$ and 2.6 $\mu$ mol $\mathrm{kg}^{-1}$ respectively. Overall, if we consider error propagation (Taylor et al. 1997) the budget uncertainty

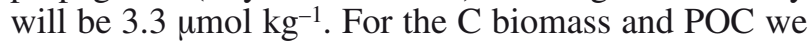
set an uncertainty of $10 \%$ following the approach of Jeansson et al. (2011). Finally, uncertainties in the $\mathrm{C}$ conversion factor for estimating phyto- and picoplankton biomass have already been discussed.

Our results also demonstrate that the NEP between summer and autumn, and much more between autumn and winter, was weakly positive. It was high between winter and spring, clearly showing a shift in the sink of $\mathrm{C}$ (Fig. 7): The contribution of $\mathrm{C}$ biomass to POC was high in Nov'06 (38\%), discrete in May'07 (10\%) and low in Jun'06 and Feb'06 (2 and 3\% respectively). Conversely the weight of picoplankton biomass to total biomass was higher in summer and winter (23 and 20\%) than in autumn and spring (5 and 11, respectively). Thus, there was an alternating pattern between larger phytoplankton and picophytoplankton. These patterns have also been described in Cerino et al. (2011).

In our study area, the average total chlorophyll- $a$ concentration increased from a low concentration in Jun'06 and Feb'07 (0.25 and $\left.0.41 \mu \mathrm{g} \mathrm{L}^{-1}\right)$ to $2.13 \mu \mathrm{g}$ $\mathrm{L}^{-1}$ in May'07, which is equivalent to an increase in phytoplankton carbon biomass from 0.40 to $3.12 \mu \mathrm{mol}$ $\mathrm{kg}^{-1}$ (Fig. 7). After the picophytoplankton carbon biomass was subtracted, the remaining carbon biomass from the other phytoplankton showed the same trend as the picophytoplankton with low values in Jun'06 (0.31 $\left.\mu \mathrm{mol} \mathrm{kg}{ }^{-1}\right)$ and high values in May'07 $\left(2.78 \mu \mathrm{mol} \mathrm{kg}{ }^{-1}\right)$. Although the conversion between chlorophyll- $a$, picophytoplankton, and carbon biomass cannot be entirely accurate, the conversion factors used are well within the commonly accepted ranges (Chiang et al. 2002), and we believe the conclusion is at least qualitatively correct. Our deduction is further supported by discussion about diatom species composition and distribution: During Feb'07, the temperature was low and a nutrient maximum appeared, favoring big phytoplankton over picophytoplankton. This could be seen as a decrease in total carbon biomass and picophytoplankton increased between Nov'06 and Feb'07. Then, once the water column began to warm up and stratification started, nutrients started to decrease and the small cells, which are better adapted to low nutrient conditions than the big ones, prevailed. This can be seen as an increase in total carbon biomass and picophytoplankton biomass in the box diagram for Feb'07 to May'07. In agreement with this observation, Chiang et al. (2002) found that in coastal waters from the East China Sea low temperatures inhibit growth in the cold season and high light attenuation limits light penetration in the warm season.

The DOC concentration varied with the same trend as the picophytoplankton carbon biomass (Fig. 7). Maximum DOC average values were found where the greatest chlorophyll- $a$ concentration existed. This is in agreement with the results from Huertas et al. (2005). However, when we observed the spatial variation in the integrated carbon pools (Fig. 6), it could be noted that in some cases the total carbon biomass coincided with DOC (off the Bay of Cádiz in Nov'07) while in other cases the total carbon biomass coincided with integrated POC values (northern area in Feb'07 and May'07).

Ribas-Ribas et al. (2011a) reported that thermodynamic control over fugacity of $\mathrm{CO}_{2}\left(f \mathrm{CO}_{2}\right)$ predominates from spring to autumn, while biological control predominates during winter. Nevertheless, the biological control should be taken into account, especially during the early spring bloom (Huertas et al. 2005).

In several Mediterranean areas a shift between respiration and primary production of microbial community metabolism has been reported on a seasonal scale (La Ferla et al. 2010, Azzaro et al. 2011). Unfortunately, eukaryotic picoplankton was not analyzed in this study.

Thus, even if mean DIC remained constant during Nov'06, Feb'07 and May'07, differences were observed in the air-sea $\mathrm{CO}_{2}$ fluxes and NEP (Fig. 7). In order to compare with the NEP, the mean total carbon biomass between two cruises was calculated. We then calculated the total amount of $\mathrm{C}$ from the phytoplanktonic pool and the NEP taking into account volume, density, surface and days between cruises. The total amount of $\mathrm{C}$ derived from the NEP is one order of 
magnitude greater than that derived from the mean total carbon biomass for the first and the third period (i.e. from Jun'06 to Nov'06 and from Feb'07 to May'07). However, $\mathrm{C}$ pools in the dissolved fractions were in the same order of magnitude between Nov'06 and Feb'07, where the biological control over $\mathrm{fCO}_{2}$ was greater, even if the NEP value was the lowest in the entire year and the $\mathrm{CO}_{2}$ flux was the highest.

\section{CONCLUSIONS}

It was observed that picophytoplankton abundance and carbon cycle parameters show a big seasonal and spatial variability in the studied area.

There was no significant positive correlation between picophytoplankton abundance and temperature, possibly due to nutrient competition with microphytoplankton.

Picophytoplankton played an important role in the regulation of the carbon cycle in the studied coastal area. During Feb'07, the contribution of the biological carbon pool was responsible for the change in the net ecosystem production.

\section{ACKNOWLEDGEMENTS}

The authors thank the crews of the R/V Mytilus and $\mathrm{R} / \mathrm{V}$ Ucádiz for their valuable assistance during the cruises. We thank the two anonymous reviewers and the associated editor for their helpful discussions and comments which have greatly improved the original manuscript. This work was supported by the Spanish CICYT (Spanish Program for Science and Technology) under contract CTM2005-01364/MAR y PO7-RNM-03197. M. R. R. was financed by the Spanish Ministry of Education with a FPU fellowship (AP2005-4791) and C. S. by an Isidro Parga Pondal contract from Xunta de Galicia.

\section{REFERENCES}

Agawin N.S.R., Agustí S. 1997. Abundance, frequency of dividing cells and growth rates of Synechococcus sp. (cyanobacteria) in the stratified Northwest Mediterranean Sea. J. Plankton Res. 19(11): 1599-1615.

Agawin N.S.R., Duarte C.M., Agustí S. 1998. Growth and abundance of Synechococcus sp. in a Mediterranean Bay: seasonality and relationship with temperature. Mar. Ecol. Prog. Ser. 170 45-53.

Agawin N.S.R., Duarte C.M., Agustí S. 2000. Nutrient and temperature control of the contribution of picoplankton to phytoplankton biomass and production. Limnol. Oceanogr. 45: 591-600.

Anfuso E., Ponce R., Castro G.C., Forja J.M. 2010. Coupling between the thermohaline, chemical and biological fields during summer 2006 in the northeast continental shelf of the Gulf of Cádiz (SW Iberian Peninsula). Sci. Mar. 74S1: 47-56.

Anfuso E. 2011. Nutrients dynamic in the coastal shelf of the Gulf of Cádiz. Ph.D thesis, Univ. Cádiz, 136 pp.

Arrigo K.R., Van Dijken L. 2007. Interannual variation in air-sea $\mathrm{CO}_{2}$ flux in the Ross Sea, Antarctica: A model analysis. J. Geophys. Res. 112: C03020.

Azzaro M., La Ferla R., Maimone G., Monticelli L.S., Zaccone R., Civitarese G. 2011. Prokaryotic dynamics and heterotrophic metabolism in a deep convection site of Eastern Mediterranean
Sea (the Southern Adriatic Pit). Cont. Shelf Res., doi: 10.1016/j. csr.2011.07.011.

Bates N.R., Hansell D.A. 1999. A high resolution study of surface layer hydrographic and biogeochemical properties between Chesapeake Bay and Bermuda. Mar. Chem. 67(1-2): 1-16.

Benson B.B., Krause D.J. 1984. The concentration and isotopic fractionation of oxygen dissolved in freshwater and seawater in equilibrium with the atmosphere. Limnol. Oceanogr. 29(3): 620-632.

Cerino F., Bernardi Aubry F., Coppola J., La Ferla R., Maimone G., Socal G., Totti C. 2011. Spatial and temporal variability of pico-, nano- and microphytoplankton in the offshore waters of the southern Adriatic Sea (Mediterranean Sea). Cont. Shelf Res. doi: 10.1016/j.csr.2011.06.006.

Chiang K.-P., Kuo M.-C., Chang J., Wang R.-H., Gong G.-C. 2002. Spatial and temporal variation of the Synechococcus population in the East China Sea and its contribution to phytoplankton biomass. Cont. Shelf Res. 22: 3-13.

Del Valls T.A., Dickson A.G. 1998. The pH of buffers based on 2-amino-2-hydroxymethyl-1,3-propanediol ("tris") in synthetic sea water. Deep-Sea Res. Part I 45, 1541-1554.

Dickson A.G. 1990. Standard potential of the $\left(\mathrm{AgCl}(\mathrm{s})+1 / 2 \mathrm{H}_{2}(\mathrm{~g})=\right.$ $\mathrm{Ag}(\mathrm{s})+\mathrm{HCl}(\mathrm{aq}))$ cell and the dissociation constant of bisulfate ion in synthetic sea water from 273.15 to 318.15 K. J. Chem. Thermodynam. 22: 113-127.

Dickson A.G., Millero F. J. 1987. A comparison of the equilibrium constants for the dissociation of carbonic acid in seawater media. Deep-Sea Res. Part A 34: 1733-1743.

Donald K.M., Joint I., Rees A.P., Wookward E.M.S., Savidge G. 2001. Uptake of carbon, nitrogen and phosphorus by phytoplankton along the $20^{\circ} \mathrm{W}$ meridian in the NE Atlantic between 57. $5^{\circ} \mathrm{N}$ and $37^{\circ}$ N. Deep-Sea Res. Part II 48: 873-897.

DuRand M.D., Olson R.J., Chisholm S.W. 2001. Phytoplankton population dynamics at the Bermuda Atlantic Time-series station in the Sargasso Sea. Deep-Sea Res. Part II 48: 1983-2003.

Echevarría F., Zabala L., Corzo A., Navarro G., Prieto L., Macías D. 2009. Spatial distribution of autotrophic picoplankton in relation to physical forcings: The Gulf of Cádiz, Strait of Gibraltar and Alborán Sea case study. J. Plankton Res. 31(11): 1339-1351.

Furnas M., Mitchell A., Skuza M., Brodie J. 2005. In the other 90\%: phytoplankton responses to enhanced nutrient availability in the Great Barrier Reef Lagoon. Mar. Pollut. Bull. 51: 253-265.

García-Fernández J.M., de Marsac N.T., Diez J. 2004. Streamlined regulation and gene loss as adaptive mechanisms in Prochlorococcus for optimized nitrogen utilization in oligotrophic environments. Microbiol. Mol. Biol. Rev. 68(4): 630-638.

García-Lafuente J., Ruiz J. 2007. The Gulf of Cádiz pelagic ecosystem: A review. Prog. Oceanogr. 74(2-3): 228-251.

Gordon Jr. D.C. 1969. Examination of methods of particulate organic carbon analysis. Deep-Sea Res. 16: 661-665.

Grasshoff K., Ehrhardt M., Kremling K. 1983. Methods of seawater analysis. Verlag Chemie, Weinheim, Germany, 419 pp.

Huertas I.E., Navarro G., Rodríguez-Gálvez S., Prieto L. 2005. The influence of phytoplankton biomass on the spatial distribution of carbon dioxide in surface sea water of a coastal area of the Gulf of Cádiz (southwestern Spain). Can. J. Bot. 83(7): 929-940.

Huertas I.E., Navarro G., Rodríguez-Gálvez S., Lubián L.M. 2006. Temporal patterns of carbon dioxide in relation to hydrological conditions and primary production in the northeastern shelf of the Gulf of Cádiz (SW Spain). Deep-Sea Res. Part II 53(11-13): 1344-1362.

Jochem F. 1988. On the distribution and importance of picocyanobacteria in a boreal inshore area (Kiel Bight, Western Baltic). $J$. Plankton Res. 10(5): 1009-1022.

Kristiansen S., Farbrot T., Naustvoll L. 2001. Spring bloom nutrient dynamics in the Oslofjord. Mar. Ecol. Prog. Ser. 219: 41-49.

La Ferla R., Azzaro M., Budillon G., Caroppo C., Decembrini F., Maimone G. 2010. Distribution to the prokaryotic biomass and community respiration in the main water masses of the Southern Tyrrhenian Sea (June and December 2005). Adv. Oceanogr. Limnol. 1(2): 235-257.

Li W.K.W, Subba Rao D.V., Smith J.C., Cullen J.J. Irwin B. and Platt T. 1983. Autotrophic picoplankton in the tropical ocean. Science 219: 292-295.

Li W.K.W., Harrison W.G., Head E.J.H. 2006. Coherent assembly 
of phytoplankton communities in diverse temperate ocean ecosystems. Proc. R. Soc., B. 273: 1953-1960.

Loring D.H., Rantala R.T.T. 1991. Manual for the geochemical analyses of marine sediments and suspended particulate matter. Earth Sci. Rev. 32: 235-283.

Macías D., Navarro G., Bartual A., Echevarría F., Huertas I.E. 2009. Primary production in the Strait of Gibraltar: Carbon fixation rates in relation to hydrodynamic and phytoplankton dynamics. Est. Coast. Shelf Sci. 83: 197-210.

Mann K.H., Lazier J.R.N. 2006. Dynamics of Marine Ecosystems: Biological-Physical Interactions in the Oceans. Blackwell Publishing Ltd., Oxford, 469 pp.

Marie D., Simon N., Vaulot D. 2005. Phytoplankton cell counting by flow cytometry. In: Andersen R. (ed.), Algal culturing techniques. Academic Press (vol. 27), pp. 253-267.

Mehrbach C., Culberson C.H., Hawley J.E., Pytkowicz R.M. 1973. Measurement of the apparent dissociation constants of carbonic acid in seawater at atmospheric pressure. Limnol. Oceanogr. 18: 897-907.

Mura M.P., Agustí S., del Giorgio P.A., Gasol J.M., Vaqué D., Duarte C.M. 1996. Loss-controlled phytoplankton production in nutrient-poor litoral waters of the NW Mediterranean: in situ experimental evidence. Mar. Ecol. Prog. Ser. 130: 213-219.

Navarro G., Ruiz J., 2006. Spatial and temporal variability of phytoplankton in the Gulf of Cádiz through remote sensing images. Deep-Sea Res. Part II 53(11-13): 1241-1260.

Navarro G., Ruiz J., Huertas I. E., García C. M., Criado-Aldeanueva F., Echevarría F. 2006. Basin-scale structures governing the position of the deep fluorescence maximum in the Gulf of Cádiz. Deep-Sea Res. Part II 53(11-13): 1261-1281.

Prieto L., Navarro G., Rodríguez-Gálvez S., Huertas I. E., Naranjo J. M., Ruiz, J. 2009. Oceanographic and meteorological forcing of the pelagic ecosystem on the Gulf of Cadiz shelf (SW Iberian Peninsula). Cont. Shelf Res. 29: 2122-2137.

Ribas-Ribas M., Gómez-Parra A., Forja J.M. 2011a. Air-sea $\mathrm{CO}_{2}$ fluxes in the north-eastern shelf of the Gulf of Cádiz (southwest Iberian Peninsula). Mar. Chem. 123: 56-66.

Ribas-Ribas M., Gómez-Parra A., Forja J.M. 2011b. Seasonal distribution of the inorganic carbon system and net ecosystem production in the north eastern shelf of the Gulf of Cádiz (southwest Iberian Peninsula). Cont. Shelf Res. 31: 1931-1942.

Ribas-Ribas M., Gómez-Parra A., Forja J.M. 2011c. Seasonal seasurface $\mathrm{CO}_{2}$ fugacity in the north-eastern shelf of the Gulf of
Cádiz (southwest Iberian Peninsula). In: Komori S, McGillis W., Kurose R. (eds.), Gas transfer at water surfaces 2010. Kyoto University Press, pp. 394-405.

Ribas-Ribas M., Gómez-Parra A., Forja J.M. 2011d. Spatio-temporal variability of dissolved organic carbon and nitrogen in a coastal area affected by river input: the north eastern shelf of the Gulf of Cádiz (southwest Iberian Peninsula). Mar. Chem. 126: 295-308

Schlitzer R. 2009. Ocean Data View, http://odv.awi.de.

Sobrino C., Montero O., Lubián, L.M. 2004. UV-B radiation increases cell permeability and damages nitrogen incorporation mechanisms in Nannochloropsis gaditana. Aquat. Sci. 66: 421-429.

Suratman S., Weston K., Grennwook N., Sivyer D.B., Pearce D.J., Jickell T. 2010. High frequency measurements of dissolved inorganic and organic nutrients using instrumented moorings in the southern and central North Sea. Est. Coast. Shelf Sci. 87: 631-639.

Taylor A.H., Geider R.J., Gilbert F.J.H. 1997. Seasonal and latitudinal dependencies of phytoplankton carbon-to-chlorophyll a ratios: results of a modeling study. Mar. Ecol. Prog. Ser. 152: 51-66.

Vargas J.M., García-Lafuente J., Delgado J., Criado F. 2003. Seasonal and wind-induced variability of Sea Surface Temperature patterns in the Gulf of Cádiz. J. Mar. Syst. 38(3-4): 205-219.

Wanninkhof R. 1992. Relationship between wind speed and gas exchange over the ocean. J. Geophys. Res. 97(C5): 7373-7382.

Weiss R.F. 1974. Carbon dioxide in water and seawater: the solubility of a non-ideal gas. Mar. Chem. 2(3): 203-215.

Worden A.Z., Nolan J.K., Palenik B. 2004. Assessing the dynamics and ecology of marine picophytoplankton: The importance of the eukaryotic component. Limnol. Oceanogr. 49(1): 168-179.

Yentsch C.S., Menzel D.W. 1963. A method for the determination of phytoplankton chlorophyll and phaeophytin by fluorescence. Deep-Sea Res. 101: 23-32.

Zubkov M.V., Fuchs B.M., Tarran G.A., Burkill P.H., Amann R. 2003. High rate of uptake of organic nitrogen compounds by Prochlorococcus Cyanobacteria as a key to their dominance in oligotrophic oceanic waters. Appl. Environ. Microbiol. 69(2): 1299-1304.

Received September 20, 2011. Accepted March 27, 2012.

Published online January 7, 2013. 